\title{
Prevalence of plaque and dental decay in the first permanent molar in a school population of south Mexico City
}

\author{
Olga Taboada-Aranza ${ }^{1 *}$ and Karen Rodríguez-Nieto ${ }^{2}$ \\ ${ }^{1}$ FES Zaragoza, Universidad Nacional Autónoma de México; ${ }^{2}$ Private practice. Mexico City, Mexico
}

\begin{abstract}
Background: The first permanent molar is susceptible to acquire tooth decay since its eruption due to its anatomy and because it has been exposed before the other teeth. Methods: An observational, prolective, transversal, and comparative study in 194 students, with a mean age of $9.9 \pm 1.8$ years. The evaluation of the dentobacterial plaque (DBP) was analyzed using the O'Leary index and the tooth decay experience with the DMFS (sum of decayed, missing, extracted and filling dental surfaces) and DMFT (sum of decayed, missing, extracted and filling per tooth) indexes. Results: The prevalence of DBP in the first permanent molar was of $99.4 \%$ and tooth decay of $57.2 \%$. The value of DMFT was $1.4 \pm 1.4$. The tooth decay experience was higher in children from 7-10 years old with a value of $2.2 \pm 2.3$, who are 7.9 times more likely to develop lesions than younger children (odds ratio $(O R)=8.9$; confidence interval $(C l)_{95 \%} 4.1-19.5, p<0.0001$ ). We found an association between age and the values of the tooth decay experience indexes; even though these were weak in the case of DMF $(r=0.439)$, the model allowed to explain $19 \%$ of the association, and $22 \%$ for DMFT $(r=0.464)$. Conclusions: Tooth decay develops rapidly in the first permanent molars; however, it does not receive the necessary care because it is usually unknown that it is a permanent tooth.
\end{abstract}

Key words: Tooth decay. Dentobacterial plaque. Permanent first molar.

\section{Prevalencia de placa dentobacteriana y caries dental en el primer molar permanente en una población escolar del sur de la Ciudad de México}

\section{Resumen}

Introducción: El primer molar permanente (PMP) es susceptible de caries a partir de su erupción por su anatomía y porque ha estado expuesto antes que otros dientes. Métodos: Estudio observacional, prolectivo, transversal, comparativo, en 194 escolares con una media de edad de $9.9 \pm 1.8$ años. La valoración de la placa dentobacteriana (PDB) se realizó con el índice de O'Leary, y la experiencia de caries con los índices CPOS (suma de superficies dentales cariadas, perdidas/extraídas y obturadas) y CPOD (suma de dientes cariados, perdidos/extraídos y obturados). Resultados: La prevalencia de PDB 
en el PMP fue del 99.4\%, y la de caries, del 57.2\%. El valor del CPOD fue de 1.4 \pm 1.4 . La experiencia de caries por superficie dental en los niños de 7.10 años de edad fue de $2.2 \pm 2.3$ y son 7.9 veces más susceptibles a desarrollar lesiones (razón de momios: 8.9; intervalo de confianza al 95\%: 4.1-19.5; $p<0.0001$ ) que los menores de esa edad. Se detectó asociación con la variable edad y los valores de los índices de experiencia de caries; aun cuando estas son débiles en el caso del CPOS ( $r=0.439)$, el modelo permitió explicar el 19\% de la asociación, y el 22\% para el CPOD ( $r=0.464)$. Conclusiones: La caries dental se desarrolla rápidamente en los PMP. En general, no se le da la importancia debida porque se desconoce que se presenta en un diente permanente.

Palabras clave: Caries dental. Placa dentobacteriana. Primer molar permanente.

\section{Introduction}

Dental caries is a widespread disease which has been and continues to be the most frequent chronic disease in the modern world. It is defined as a chronic dynamic process or disease that occurs in the tooth structure when is in contact with an accumulation of bacterial plaque, specifically with microbial deposits. As a result of the imbalance between the dental substance and the dental plaque fluid, a mineral loss of the tooth surface occurs, distinguished by the localized destruction of hard tissue ${ }^{1}$.

The World Health Organization states that dental caries is still considered one of the conditions that most compromises oral health. $98 \%$ of the world population suffers from dental caries and approximately $90 \%$ of school children between 5 and 17 years old suffer from it. In the scientific literature, it is reported that dental caries presents a sustained increase with age, at 7 years old the DMFT index value (sum of teeth that are Decayed, Missing or Filled) is 1.7 teeth, but at 14 years old this value increases to 7.4 teeth $^{2}$.

Dental caries has been considered the most important disease in the history of oral morbidity worldwide. Currently, its distribution and severity vary from one region to another, and its appearance is mostly associated with socio-cultural, economic, environmental and behavioral factors ${ }^{3,4}$. Although its prevalence has decreased in the industrialized countries, it still affects between $60-90 \%$ of both child and adult populations ${ }^{5}$.

Scientific evidence shows that a good personal oral hygiene reduces the experience of dental caries. Thou$\mathrm{gh}$, there is little evidence to attribute the preventive value of good oral hygiene in dental caries. However, due to the importance of the dental plaque presence in the development of caries, oral hygiene is critical in the control of this pathology in a high-risk patient. Studies have reported the loss of the first permanent molar in $63.9 \%$ of cases of poor oral hygiene ${ }^{6}$, which means that, when oral hygiene becomes difficult due to an impairment age, the risk of dental caries increases.
Dental caries develops rapidly in the first permanent molars and can evolve-within only six months-from an incipient lesion to advanced lesions with marked exposure of the pulp chamber, so the extraction of affected molars is frequent. Parents often do not know what a permanent tooth is, so they do not give the necessary importance to their care as they have low motivation for oral health. Unfortunately, it is for this reason that the loss of the first permanent molar occurs at an early age ${ }^{7}$.

The presence of the first permanent molar is important because it determines the chewing pattern that the individual will have during his life. Also, it has a unique role by performing most of the work of chewing and crushing food. This molar is susceptible to caries from its eruption, around 6 years of age, either because of its anatomy or because it is exposed to caries before other teeth. Potential sequelae of the first permanent molar loss include mesial migration and overeruption due to the loss of interocclusal space, among others ${ }^{8}$.

The first permanent molar is a tooth structure that determines the development of dental occlusion. By occupying an ample space in the posterior dental area, its presence determines the balance of the occlusion and an adequate masticatory function. It is also one of the first permanent teeth that accompany the child's primary dentition, transforming it into a mixed dentition?.

In this context, it was considered necessary to investigate the prevalence of dentobacterial plaque (DBP) and dental caries in the first permanent molar and to evaluate the association of sex, age, and DBP as risk factors for dental caries in a school population in the south of Mexico City.

\section{Methods}

An observational, prolective, cross-sectional, comparative study was conducted in a population of 194 students selected by a non-probabilistic convenience 
sampling. The inclusion criteria included: students that had at least two permanent first molars (PFM) and that had the parent or guardian informed consent; the exclusion criterion was the scholar's desire to not participate in the study, despite having informed consent.

The research began with the calibration of the clinical diagnosis of dental caries, obtaining reliability of $\mathrm{k}=$ 0.94 (confidence interval (Cl) 95\% 83-100). Subsequently, we proceeded to the clinical assessment of DBP with the O'Leary index (percentage of dental surfaces covered with bacterial plaque), and of dental caries with the DMFS (sum of surfaces that are Decayed, Missing or Filled) and DMFT indexes.

The clinical assessment of DBP and dental caries was carried out in a dental office located inside the primary school.

All children were assessed before the recess, to avoid the presence of increased DBP produced by the extra food intake during the break.

Data were analyzed with the statistical package SPSS 11.5 (SPSS Inc. Michigan IL, USA), with this purpose the descriptive statistics (relative frequencies) of the study variables were obtained. Statistical significance of the quantitative variables was assessed with Student's t-test and of the qualitative variables with the $\mathrm{X}^{2}$ test at a significance level of $95 \%$. Also, the dental caries risk estimate was calculated through the odds ratio $(\mathrm{OR})$ to determine the probable relationship between the variables sex, age, and DBP with the presence of dental caries. For the PFM, a simple linear regression model was performed.

\section{Results}

The study population consisted of 194 students, selected by a non-probabilistic convenience sampling, attending the public primary school Anton Semionovich Makarenko, located in the Coyoacán borough in the south of Mexico City. The average age was $9.0 \pm$ 1.8 years (range $6-13$ ); $53 \%$ of the students (102) were males.

The prevalence of DBP in the PFM was $99.4 \%$ of the total number of students. Table 1 shows that the proportion of students with more than $20 \%$ of the PFM dental surfaces covered by DBP was higher for males and schoolchildren $>7.09$ years of age. The O'Leary index value for the school population was $48.1 \%$ (95\% confidence interval (Cl) 46.3, 49.7).

The prevalence of caries in the PFM of the study population was $57.2 \%$. The presence of caries in the PFM evaluated with the DMFT index was $1.4 \pm 1.4$; the
Table 1. Frequency distribution and percentage of dentobacterial plaque according to schoolchildren's sex and age.

\begin{tabular}{|c|c|c|}
\multirow{2}{*}{ Variable } & \multicolumn{2}{|c|}{ Dentobacterial plaque ${ }^{\mathrm{a}}$} \\
\cline { 2 - 3 } & $\leq \mathbf{2 0 \%}$ & $>\mathbf{2 0 \%}$ \\
\hline Sex & & \\
Male & $11(10.8 \%)$ & $91(89.2 \%)$ \\
Female & $16(17.4 \%)$ & $76(82.6 \%)$ \\
Age & $8(16.3 \%)$ & $41(83.7 \%)$ \\
$\leq 7.09^{b}$ & $19(13.1 \%)$ & $126(86.9 \%)$ \\
$>7.09$ & $27(13.9 \%)$ & $167(86.1 \%)$ \\
Total & $27 \%$
\end{tabular}

a Dental caries risk $>20 \%$, surfaces covered with dentobacterial plaque; ${ }^{b} 25^{\text {th }}$ percentile, no risk.

highest caries category had a value of $1.2 \pm 1.3$. In the analysis by sex, the highest value was for the female sex $(1.5 \pm 1.4)$. The highest index value by age group was for $>7.09$ years, with a DMFT of $1.7 \pm 1.4$; this difference was statistically significant compared to those of younger age. For students with $>20 \%$ of dental surfaces covered with DBP, the index was $1.5 \pm 1.4$, with a statistically significant difference compared to those with $\leq 20 \%$ of surfaces covered with bacterial plaque (Table 2).

The DMFS index value was $1.7 \pm 2.2$ with the highest caries category and had an average of $1.5 \pm 1.8$. In the analysis by sex, the highest value was in the female sex $1.8 \pm 2.3$. By age group, the highest DMFS index value was $2.2 \pm 2.3$ in schoolchildren $>7.09$ years, with statistically significant differences compared to children under that age. For students with $>20 \%$ of surfaces covered with DBP, the index value was $1.8 \pm 2.3$ (Table 3).

Of the analyzed risk factors, the exposure time measured by the age showed that schoolchildren $>7.09$ years old have a 7.9 times higher risk of dental caries in the PFM compared to children under that age, with a statistically significant difference $(\mathrm{OR}=8.9,95 \%$ $\mathrm{Cl}=4.1,19.5 ; p>0.0001)$. The DBP presence was also a risk factor to present caries in the PFM, with a 2.1 times higher value in schoolchildren that present $>20 \%$ of surfaces covered by DBP $(\mathrm{OR}=3.1,95 \% \mathrm{Cl}=1.3$, 7.4; $p<0.01$ ) (Table 4).

In the simple linear regression analysis (Figure 1) an association was found between the predictor variable (age) and the response variables (DMFS and DMFT indices). Even though the association was weak -according to Colton criteria - the model explains $19 \%$ of the association between age and DMFS $(r=0.43$, 
Table 2. Mean and standard deviation per DMFT index category of the permanent first molar, by sex, age, and DBP covered areas.

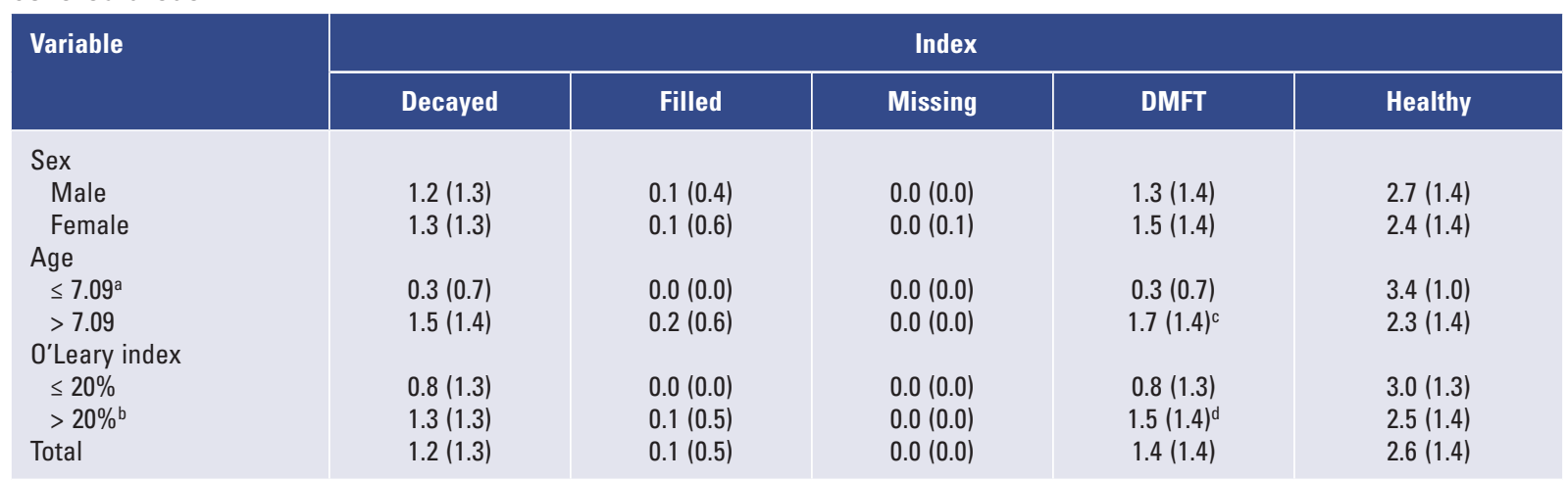

DMFT (sum of teeth that are Decayed, Missing or Filled): Index of dental caries per tooth unit.

${ }^{\mathrm{a}} 25^{\text {th }}$ percentile, no risk; bental caries risk, percentage of surfaces covered with dentobacterial plaque; ${ }^{c} p<0.0001$, Student's t-test; ${ }^{\mathrm{d}} p<0.04$.

Table 3. Mean and standard deviation per DMFS index category for the permanent first molar, by sex, age, and DBP covered areas.

\begin{tabular}{|c|c|c|c|c|c|}
\hline \multirow[t]{2}{*}{ Variable } & \multicolumn{5}{|c|}{ Index } \\
\hline & Decayed & Filled & Missing & DMFS & Healthy \\
\hline \multicolumn{6}{|l|}{ Sex } \\
\hline Male & $1.4(1.8)$ & $0.1(0.6)$ & $0.0(0.0)$ & $1.6(2.1)$ & $18.0(2.5)$ \\
\hline Female & 1.5 (1.7) & $0.2(0.8)$ & $0.0(0.5)$ & $1.8(2.3)$ & $17.6(2.9)$ \\
\hline \multicolumn{6}{|l|}{ Age } \\
\hline$\leq 7.09^{\mathrm{a}}$ & $0.3(0.9)$ & $0.0(0.0)$ & $0.0(0.0)$ & $0.3(0.9)$ & $18.2(3.6)$ \\
\hline$>7.09$ & $1.9(1.8)$ & $0.0(0.4)$ & $0.2(0.8)$ & $2.2(2.3)^{c}$ & $17.7(2.3)$ \\
\hline$\leq 20 \%$ & $1.0(1.6)$ & $0.0(0.0)$ & $0.0(0.0)$ & $1.0(1.6)$ & $18.0(3.2)$ \\
\hline$>20 \%^{b}$ & $1.6(1.8)$ & $0.0(0.3)$ & $0.2(0.8)$ & $1.8(2.3)$ & $17.8(2.6)$ \\
\hline Total & 1.5 (1.8) & $0.2(0.7)$ & $0.0(0.3)$ & $1.7(2.2)$ & $17.8(2.7)$ \\
\hline
\end{tabular}

DMFS: Index of dental caries per dental surface.

${ }^{a} 25^{\text {th }}$ percentile, no risk; ${ }^{b}$ dental caries risk, the percentage of surfaces covered with dentobacterial plaque; ${ }^{c} p<0.0001$, Student's t-test.

Table 4. Risk factors for dental caries in the permanent first molar of school-age children

\begin{tabular}{|l|c|c|c|}
\hline Variable & OR & $95 \%$ CI & $\boldsymbol{p}$ value $^{\mathbf{a}}$ \\
\hline Age > 7.09 años & 8.9 & $4.1-19.5$ & 0.0001 \\
\hline 20\% dental surfaces & & & \\
covered with DBP & 3.1 & $1.3-7.4$ & 0.007 \\
Male sex & 1.4 & $0.8-2.5$ & 0.205 \\
\hline
\end{tabular}

OR, odds ratio, univariate analysis; $\mathrm{Cl}, 95 \%$ confidence interval; $\mathrm{DBP}$, dentobacterial plaque.

${ }^{a} \mathrm{p}$ value obtained by $\mathrm{X}^{2}$ test.

$\left.p<0.0001, r^{2}=0.19, p<0.0001\right)$, and $22 \%$ of the association with DMFT $\left(r=0.46, p<0.0001, r^{2}=0.22\right.$, $\mathrm{p}<0.0001)$.

\section{Discussion}

Dental caries is one of the most prevalent oral diseases and the primary cause of tooth loss. The PFM is the most susceptible tooth to the acids produced by the DBP bacteria because of its early appearance in the oral cavity, morphology and functional characteristics.

Several studies show that the dental caries prevalence is in a range of $60 \%$ to $90 \%$. Concerning the PFM caries prevalence, a study conducted in the Tláhuac borough in Mexico City showed a $58.6 \%$ prevalence, a value slightly higher than that found in the present study, which was $57.2 \%$. Also, the female sex had a higher number of PFMs with dental caries, a similar finding to the reported in this study ${ }^{10}$.

In a study conducted in Chile, Zaror et al. reported a caries prevalence in the PFM of $68 \%$, a higher number than the one obtained in the current work ${ }^{11}$.

In another study conducted in Cuba by Quesada et al. (2010) a $57.6 \%$ caries prevalence in the PFM in female minors was reported, a value similar to the found in the present work. The authors pointed out that the age group 

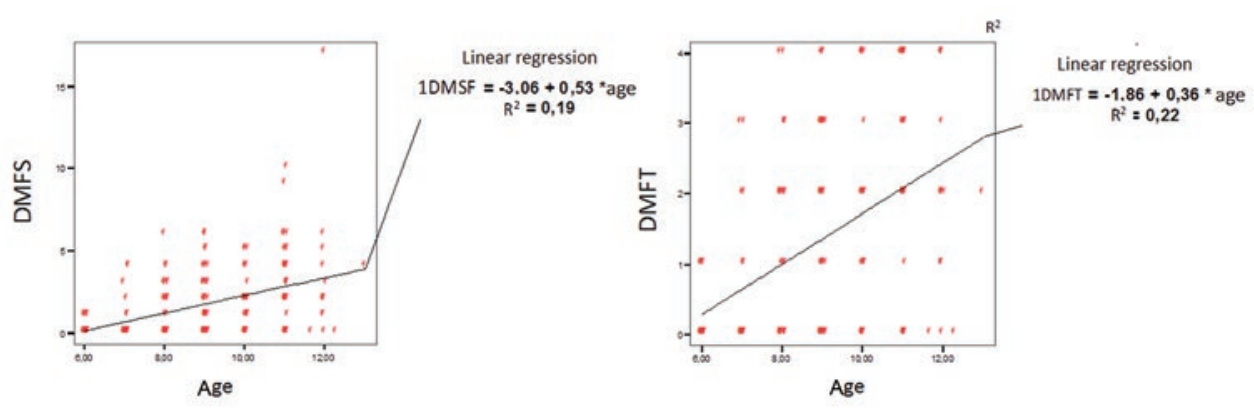

Figure 1. Linear regression of the predictive variable, age, as an estimate of time exposure to risk factors for dental caries in the permanent first molar (PFM), and the response variables: DMFS (sum of surfaces that are Decayed, Missing or Filled) and DMFT (sum of teeth that are Decayed, Missing or Filled).

with the most significant affectation was the 12-14 years' age group, similar to what we found in the current work ${ }^{12}$. Interestingly, the study conducted by Rodríguez et al., also in a Cuban population, reported a caries prevalence in the PFM of $52.4 \%$ in the male sex, unlike the present results. Also, they found a high DBP prevalence by using the modified Green and Vermillion index where they observed regular oral hygiene in $80.7 \%$ of males and $80.1 \%$ of females ${ }^{13}$.

In a study in which oral hygiene was assessed in school-age children using the simplified oral hygiene index (OHI-S), good dental hygiene was reported in $51.1 \%{ }^{14}$. Due to the type of index used, no reference is made to this study, however, the low prevalence of dental plaque was remarkable.

In Venezuela, a DBP prevalence study was conducted in which an O'Leary index of $43.1 \%$ in school-age children was reported, which agrees with the results of the current work, in which the high DBP prevalence is a risk factor to present dental caries ${ }^{15}$.

A study conducted by Discacciate and Lértora, in Argentina, showed that the caries prevalence of the PFM was $52 \%$, and was higher in the population of 7 years of age $(58.3 \%)$. These data agree with the results of the present work ${ }^{16}$.

Another study in Venezuela reported that the age group with more pathological conditions of the PFM was the one in the first decade of life, with a prevalence of $70 \%$. A similar finding was reported in the present investigation ${ }^{9}$.

Moreno et al. conducted a study in Mexico City in which a high prevalence of caries was reported in school-age children of Mexico City public schools ${ }^{17}$.

In contrast, the results of Meneses et al. differed with the current work since the caries prevalence in the PFM was of only $20.3 \%$ in a population of school-age children in the city of Medellín ${ }^{18}$.

The DBP has the most important role in the appearance of dental caries; however, it is not the only element that intervenes in its development since not all bacterial-forming colonies within the biofilm affect dental tissues. Dental caries is associated with multiple biological, systemic and socioeconomic risk factors, whose combination can modify the course and aggressiveness of the disease, so it is necessary to search and analyze other risk factors.

\section{Ethical disclosures}

Protection of human and animal subjects. The authors declare that no experiments were performed on humans or animals for this study.

Confidentiality of data. The authors declare that they have followed the protocols of their work center on the publication of patient data.

Right to privacy and informed consent. The authors have obtained the written informed consent of the patients or subjects mentioned in the article. The corresponding author is in possession of this document.

\section{Conflicts of interest}

The authors declare no conflicts of interest.

\section{References}

1. González BY, Sexto DN, Francisco LA, Vázquez DA. Comportamiento de la caries dental en el primer molar permanente en escolares. Medisur. 2009;7:4. Available at: http://www.medisur.sld.cu/index.php/medisur/article/view/587.

2. Carrero G, Fleitas A, Arellano L. Prevención de caries dental en primeros molares permanentes utilizando sellantes de fosas y fisuras y enjuagues bucales fluorados. Rev Odont Andes. 2006;1:44-53. 
3. Cid RM, Álvarez ÁM, Alfonso PC, Montes de Oca RR. Influencia de los determinantes sociales en la salud del primer molar permanente. Rev Med Electrón. 2017;39:158-69. Available at: http://revmedicaelectronica. sld.cu/index.php/rme/article/view/2108/pdf 216.

4. Sales-Peres SH, Bastos JR. An epidemiological profile of dental caries in 12-year-old children residing in cities with and without fluoridated water supply in the central western area of the State of São Paulo, Brazil. Cad Saúde Pública. 2002;18:1281-8.

5. Tascón J, Aranzazu L, Velasco T, Trujillo K, Paz M. Primer molar permanente: historia de caries en un grupo de niños entre los 5 y 11 años frente a los conocimientos, actitudes y prácticas de sus madres. Rev Colomb Med. 2006;36:41-6.

6. Sánchez MD, Pons LY, Betancourt GA, Santateresa MA. Pérdida del primer molar permanente: factores de riesgo y salud bucodental en adolescentes. Rev Finlay. [Internet]. 2017;7:17-25. Available at: http:// scielo.sld.cu/pdf/rf/v7n1/rf04107.pdf

7. Guerra M, Rodríguez C, Carrasco W, Tovar V, López L. Prevalencia de caries en el primer molar permanente en niños VIH (+) vs VIH (-). Acta Odontol Venez. 2012;51:9. Available at: http://www.actaodontologica. com/ediciones/2013/1/art9.asp?print=true

8. Casanova RA, Medina SC, Casanova RJ, Vallejos SA, Maupomé G, Kageyama EM. Factores asociados a la pérdida del primer molar permanente en escolares de Campeche, México. Acta Odontol Venez. 2005;43:268-75.

9. Bermúdez S, González AV, Márquez JD, Restuccia G, Kammann MA Zambrano $\mathrm{O}$, et al. Prevalencia de caries y tratamientos realizados en el primer molar permanente en la población de Río Chico. Estado Miranda, Venezuela. Acta Odontol Venez. 2013;51:9. Available at: http://www. actaodontologica.com/ediciones/2013/4/art12.asp?print=true

10. Oropeza OA, Molina FN, Castañeda CE, Zaragoza RY, Cruz LD. Caries dental en primeros molares permanentes de escolares de la delegación Tláhuac. ADM. 2012;69:63-8.
11. Zaror SC, Pineda TP, Villegas VM. Estudio clínico del primer molar permanente en niños de 6 años de edad de la Comuna de Calbuco, Chile. Acta Odontol Venez. 2012;49:8. Available at: http://www.actaodontologica.com/ediciones/2011/3/art3.asp

12. Quesada AC, Hernández GM, Carbó AJ, Quesada AL. Urgencia estomatológica por caries en los primeros molares permanentes en menores de 15 años. Medicentro. 2010;4:12-24.

13. Rodríguez OF, Mursulí SM, Pérez GL, Martínez RM. Estado de salud del primer molar permanente en niños de 6-11 años. Sancti Spíritus. 2011. Gac Med Espirit. 2013;15:37-47.

14. Murrieta PF, Juárez LL, Linares VC, Zurita MV. Prevalencia de gingivitis en un grupo de escolares y su relación con el grado de higiene oral y el nivel de conocimientos sobre salud bucal demostrado por sus madres. Bol Med Hosp Infant Mex. 2004:61:44-54.

15. Agreda M, Hernández M, Salinas $P$, Acevedo J, Acostai G, Chacón C, Ramírez E. Presencia de placa dental en alumnos de quinto grado de la Escuela Básica "Eloy Paredes". Mérida, Venezuela. MedULA. 2008; 17:95-9.

16. Discacciate de LM, Lértora M. Primer molar permanente: riesgo y afecciones en sus primeros años. Universidad Nacional del Nordeste, Comunicaciones científicas y tecnológicas. Cátedra de Odontopediatría, Facultad de Odontología; 2004. Available at: http://www.unne.edu.ar/ unnevieja/Web/cyt/com2004/3-Medicina/M-030.pdf

17. Moreno AA, Carreón GJ, Alvear GG, López MS, Vega FL. Riesgo de caries en escolares de escuelas oficiales de la Ciudad de México. Rev Mex Ped. 2001;68:228-33.

18. Meneses-Gómez E, Vivares-Builes A, Botero-Botero A. Condición del primer molar permanente en una población de escolares de la ciudad de Medellín 2012. CES Odontol. 2013;26:24-32. Available at: http://www. scielo.org.co/scielo.php?script=sci_abstract\&pid=S0120-971X2013 $000100003 \&$ lng=es\&nrm=iso\&tlng=en 